This is the peer-reviewed, post-print version of the paper:

Tan, T., Lu, W., Tan, G., Xue, F., Chen, K., Xu, J., Wang, J. \& Gao, S. (2020).

Construction-Oriented Design for Manufacture and Assembly (DfMA) Guidelines.

Journal of Construction Engineering and Management, in press.

This material is shared under the permission of ASCE, and may be downloaded for personal use only. Any other use requires prior permission of ASCE. The official version of this paper may be accessed at $L I N K_{-} T O \_I N S E R T$

\author{
Tan Tan ${ }^{1}$, Weisheng $\mathrm{Lu}^{2 *}$, Gangyi Tan ${ }^{3}$, Fan Xue ${ }^{4}$, Ke Chen ${ }^{5}$, Jinying $\mathrm{Xu}^{6}$, Jing Wang ${ }^{7}$, and
} Shang $\mathrm{Gao}^{8}$

\title{
Construction-Oriented Design for Manufacture and Assembly (DfMA) Guidelines
}

\section{Abstract}

The pursuit of modern product sophistication and production efficiency has bolstered Design for Manufacture and Assembly (DfMA) around the world. Being both a design philosophy and a methodology, DfMA has existed in manufacturing for decades. It is coming into vogue in construction as a potential solution to the industry's lackluster productivity amid enduring exhortation of cross-sectoral learning. However, many studies of DfMA in construction are still simply following the DfMA guidelines developed from manufacturing without adequately considering important differences between the two sectors of construction and manufacturing. This study aims to develop a series of construction-oriented DfMA guidelines by adopting a mixed-method approach. It critiques existing DfMA guidelines in relation to the characteristics of construction, and further argues that construction-oriented DfMA should consider five fundamental aspects: contextual basis, technology rationalization, logistics optimization, component integration, and material-lightening, either individually or collectively. A case study is then conducted to substantiate and verify the feasibility of these guidelines. This research sheds new light on the cross-sectoral learning of DfMA from manufacturing to construction. The guidelines can be used as the benchmark for the evaluation of manufacturability and

\footnotetext{
${ }^{1}$ Ph.D. Student, The Bartlett School of Construction \& Project Management, University College London, UK, e-mail: tan.tan.17@ucl.ac.uk;

${ }^{2}$ Professor, Corresponding Author, Department of Real Estate and Construction, The University of Hong Kong, Hong Kong SAR, e-mail: wilsonlu@hku.hk, Tel.: +852 3917 7981;

${ }^{3}$ Professor, Department of Architecture, Huazhong University of Science and Technology, China, tan_gangyi@ 163.com;

${ }^{4}$ Assistant Professor, Department of Real Estate and Construction, The University of Hong Kong, Hong Kong SAR, e-mail: xuef@hku.hk;

${ }^{5}$ Associate Professor, Department of Construction Management, Huazhong University of Science and Technology, China, email: chenkecm@hust.edu.cn;

${ }^{6}$ Ph.D. Candidate, Department of Real Estate and Construction, The University of Hong Kong, Hong Kong SAR, e-mail: jinyingxu@connect.hku.hk;

${ }^{7}$ Ph.D. Candidate, Department of Real Estate and Construction, The University of Hong Kong, Hong Kong SAR, e-mail: jingww@ connect.hku.hk;

${ }^{8}$ Lecturer, Faculty of Architecture, Building and Planning, The University of Melbourne, Australia, e-mail:

shang.gao@unimelb.edu.au.
} 
assemblability in practice. It also opens up a new avenue for further DfMA studies in construction.

Keywords: Design for manufacture and assembly; Architecture; Construction; Manufacturing; Assembly; Design guidelines

\section{Introduction}

Design for Manufacturing and Assembly (DfMA) is both a design philosophy and methodology whereby the downstream processes of manufacturing and assembly are considered when designing products (Boothroyd, 2005). Originating from the manufacturing industry, DfMA suggests a systematic design process that integrates the production experience into the product design (Corbett et al., 1991; Kuo et al., 2001; Harik and Sahmrani, 2010). It has two components: design for manufacture (DfM) and design for assembly (DfA). DfM compares selected materials and manufacturing processes for the parts, determines the cost impact of those materials and processes, and finds the most efficient use of the component design (Ashley, 1995), while DfA addresses the means of assembling the parts (Bogue, 2012). Altogether, DfMA represents a shift from a traditional, sequential approach to a non-linear, reiterative design methodology. Since its emergence during World War II and flourishing in the 1960s 1970s, numerous DfMA guidelines (e.g., Boothroyd, 2005; Swift and Brown, 2013; Bogue, 2012; Emmatty and Sarmah, 2012) have been developed to help designers to operate this design philosophy to improve designs, productivity and profitability (Gatenby and Foo, 1990; Kuo et al., 2001). More recently, a 'Design for Excellence' (DfX) approach has developed where the ' $\mathrm{X}$ ' may denote excellence in any aspect, including testability, compliance, reliability, manufacturability, inspection, variability, and cost (Maskell, 2013; Huang, 2012).

DfMA is now beginning to come into vogue in the construction industry. Notably, the Royal Institute of British Architects (RIBA) (2013) published a DfMA overlay to its Plan of Work 2013. The governments of the UK, Singapore, and Hong Kong have all published DfMA guides or emphasized its importance in construction. Industry giants such as a Laing O'Rourke (2013) and Balfour Beatty (2018) have even indicated that they consider DfMA to be the future of construction.

Some terminologies need to be clarified here. According to Dainty et al. (2007), precisely what constitutes construction is subject to a range of boundary definitions. There are narrow and broad definitions of construction (Pearce, 2003). The narrow definition of construction focuses on onsite assembly and the repair of buildings and infrastructure. Contrastingly, the broad definition of construction could include quarrying of raw materials, manufacture of building materials, sale of construction products (Dainty et al., 2007), and professional services such as architectural design, urban planning, landscape architecture, engineering design, surveying, construction-related accountancy, and legal services (Jewell et al., 2014). All the above sub- 
sectors can be allocated a four-digit U.S. SIC (Standard Industrial Classification) code, which is in accordance with the United Nation's International SIC or the U.K. SIC (Lu et al., 2013). At the risk of oversimplification, this study treats upstream architecture and engineering activities as "design", and downstream onsite activities as "construction". Onsite construction is traditionally conducted using cast in-situ; it is a combination of fabrication and assembly (Ballard and Howell, 1998). In recent years, the global construction industry has seen a number of initiatives to minimize onsite construction, shifting it to downstream offsite "manufacture"/fabrication but bringing it back onsite for "assembly" (Duncan in RIBA 2013). To understand the concept of DfMA in construction, one must position it in the heterogeneous context of construction and be cognizant of the relationships between architecture, engineering, construction, manufacturing, and assembly therein.

One can also understand the DfMA trend against the background of global construction, which is characterized by ever-heightened product sophistication, sluggish productivity growth, increasing influence of cross-sectoral learning, and emerging technological advancements in virtual design and construction. Production inefficiency in construction has been criticized in a succession of influential UK-based industry reports, including 'Constructing the Team' (Latham, 1994), 'Rethinking Construction' (Egan, 1998), 'Never Waste a Good Crisis' (Wolstenholme et al., 2009), and more recently in The Economist (2017) comparing construction productivity with its manufacturing and agriculture counterparts. Construction has been accused of being 'adversarial', 'ineffective', 'fragmented', and 'incapable of delivering', with an appalling backwardness that should be improved, e.g., through industrial structure or organizational culture. Increasingly, it is exhorted that construction should look to and learn from highly productive industries such as advanced manufacturing (Camacho et al., 2018). Lean construction (Koskela, 1992) is typically advocated as a result, as is DfMA.

The exploration of production innovation, in particular offsite construction, has provided an unprecedented opportunity for DfMA. It is the similarities between offsite construction/prefabrication and manufacturing that have pushed DfMA to the fore of the industry's cross-sectoral learning and innovation agenda. In addition, emerging technological advancements, such as Building Information Modelling (BIM), 3D printing, the Internet of Things (IoTs), and robotics provide the construction industry, DfMA in particular, new entry points for manufacturing knowledge and efficiency improvement.

However, current DfMA practices in construction still, by and large, follow DfMA guidelines developed in a manufacturing context without sufficiently considering the differences between construction and manufacturing. For example, DfMA procedures in Boothroyd (2005) consider DfA and DfM but not the downstream logistics and supply chain (LSC), which plays a critical role in offsite prefabrication construction. Some construction DfMA guidelines proposed, e.g., Gbadamosi et al., (2019), Kim et al., (2016), and Banks et al. (2018), originate more or less 
from manufacturing-oriented guidelines. While inspiring, some of these guidelines are not necessarily a good fit with construction's characteristics, leading to an inability to improve manufacturing and assembly. Some guidelines are proposed in a fragmented fashion without necessarily forming an organic whole, leading to a lack of comprehensiveness, or "easy to use" throughout the building process. The RIBA, in recognizing the potential of DfMA in construction, added an overlay of DfMA to its time-honored Plan of Work. Following RIBA's vision (2013, p. 24), much "soft-landing" work remains to implement DfMA in construction.

Partly responding to this call for "soft-landing" work, this paper aims to facilitate the implementation of DfMA in construction by proposing a series of construction-oriented DfMA guidelines. It has three objectives: (1) to identify the differences between manufacturing and construction; (2) to propose a series of construction-oriented DfMA guidelines; and (3) to evaluate the proposed DfMA guidelines by using empirical evidence. These objectives are achieved using a mixed-method approach including literature review, comparative analysis, and case study. The remainder of this paper is organized into six sections. Section 2 presents basic knowledge such as the origin, concept, and general applications of DfMA. Section 3 describes the research methods adopted. Section 4 introduces the development of DfMA guidelines for construction projects by adapting existing DfMA guidelines to fit the characteristics of the design process and the final product in construction. In Section 5, the developed DfMA guidelines are evaluated through empirical evidence from research and practice. The last two sections present discussions and a conclusion, respectively.

\section{An overview of Design for Manufacture and Assembly}

DfMA originated in the weapon production processes developed by Ford and Chrysler during World War II. Formal approaches to DfM and DfA emerged in the late 1960s and early 1970s when the UK published The Management of Design for Economic Production standard in 1975. The academic exploration of DfMA can be traced back to the 1970s when Boothroyd and Dewhurst conducted research and practice in this area. Boothroyd (1994) described the shortcomings of an "over the wall" design approach and suggests the application of DfMA methodology to making production knowledge available to designers. Hamidi and Farahmand (2008) suggested that DfMA implementation needs a feedback loop between design and manufacturing; for example, with a design being checked by the manufacturer to identify potential problems or waste in the downstream processes of manufacturing and assembly.

Since its adoption in manufacturing, DfMA has helped many companies increase their profits through optimized design (Gatenby and Foo, 1990; Kuo et al., 2001). Several guidelines have been consolidated to help designers reduce difficulties in manufacturing and assembling a product. Examples include minimizing the number of parts (Kuo et al., 2001; Eastman, 2012; Bogue, 2012) and searching for the most efficient use of modular design (Ashley, 1995). Some analytical tools have also been developed for designers to evaluate their proposed design from 
the perspectives of manufacturing and assembly difficulties. Although these guidelines/principles have been developed from various reference points, they share substantial similarities, with minimization, standardization, and modular design emerging as key DfMA principles.

The importance of considering the production process in the design stage is also recognized by the construction industry. Architectural and engineering design have never been a pure art; there is a long-standing architectural philosophy of "form follows function" (Goulding et al., 2015) whereby form, functions, quantity, and buildability should be considered in design. Design optimization has been advocated. But DfMA is different in that it consciously highlights the downstream processes of manufacturing and assembly. With its success in the manufacturing, civil aviation, auto, and other industries, researchers have suggested the implementation of DfMA in construction to harvest benefits including time reduction, cost minimization, and achieving customer satisfaction. Although DfMA has only recently been introduced to construction, some DfMA-like thinking precedes it. For example, Fox et al. (2001) proposed a strategy for DfM application to buildings, and Crowther (1999) proposed design for disassembly as the final step of DfA in construction for life cycle assemblability. More recently, Yuan et al. (2018) integrated BIM and DfMA to develop the concept and process of DfMAoriented parametric design, and Arashpour et al. (2018) explained DfMA guidelines in modular prefabrication of complex façade systems. Chen and $\mathrm{Lu}$ (2018) also highlighted the application of DfMA in the façade system through a case study. In addition to this research work, industrial reports such as Laing O'Rourke (2013), Balfour Beatty (2018), and RIBA's DfMA overlay (2013) have helped popularize DfMA in construction.

Despite support from both academia and industry, DfMA has yet to achieve fervent implementation in construction because of problems related to new design system and standardization, fragmentation, multi-party coordination, and lack of proper design guidelines (Jin et al., 2018; Gao et al., 2018). Few studies, if any, have discussed the differences of DfMA's guidelines between manufacturing and construction. Indiscriminate introduction of guidelines from a manufacturing to construction may not increase productivity, and will definitely pose additional uncertainties and risks (Paez et al. 2005).

\section{Research methods}

This study adopts a four-step research design, as shown in Figure 1. The first step is to review fundamental guidelines of DfMA widely adopted in the manufacturing industry. These guidelines are retrieved from authoritative publications, including academic papers and reports. Some of these guidelines can be applied to the design of building components for efficient construction, but others cannot. Therefore, the second step is to generate a tentative set of DfMA guidelines applicable to construction. This process is delivered based on an understanding of the similarities and differences between construction and manufacturing. The third step is to 
complement the tentative DfMA guidelines by analyzing construction projects that have pioneered DfMA-oriented design. The set of DfMA guidelines will be further validated in the fourth and final step of this study.

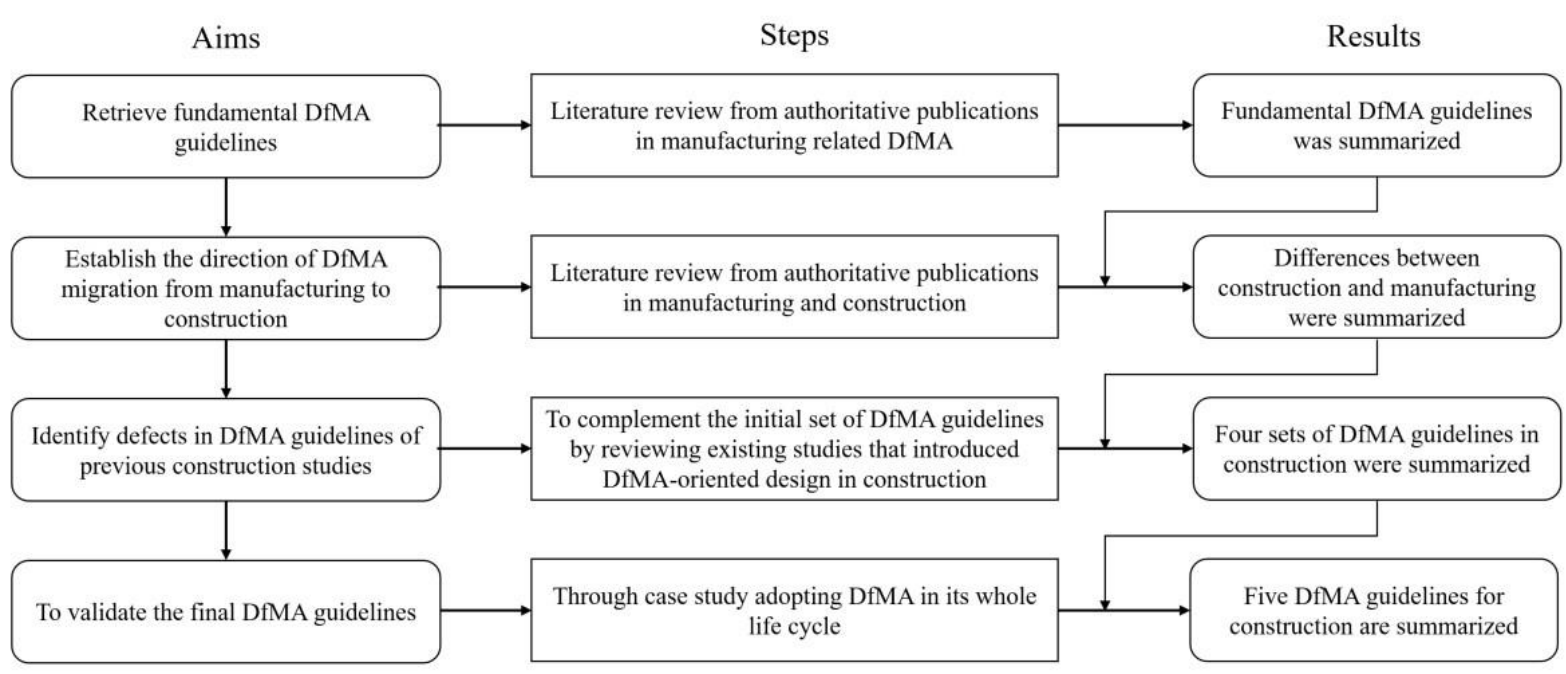

Fig. 1. Research design and methods

Three principles underpin the transplantation of DfMA guidelines from manufacturing to construction. The first is to reduce inappropriate guidelines and merge or amend vague guidelines. Some guidelines that cannot meet the production requirements of construction due to its unique characteristics will be deleted. Guidelines that are too vague or not amenable to accurate and efficient implementation will be re-organized or re-presented. The second principle is to increase applicable guidelines in line with the unique characteristics of construction. Manufacturing-oriented DfMA guidelines may not fully describe the needs of manufacturability and assemblability in construction projects. Properly enhanced, these DfMA guidelines, however, can provide decision-makers with adequate design options. The third principle is to establish DfMA guidelines using a systems theory lens. Many DfMA guidelines developed from the manufacturing industry are, in fact, appropriate only from a micro perspective. Using these guidelines discretely without systematic consideration might not increase manufacturability and assemblability in real-life construction projects.

\section{Towards construction-oriented DfMA guidelines}

\section{DfMA guidelines for manufacturing}

DfMA signifies a shift in traditional, sequential design thinking to a non-linear, reiterative methodology by actively considering the downstream processes in the upfront design stage. Researchers such as Stoll (1986), Swift and Brown (2013), Bogue (2012), and Emmatty and Sarmah (2012) provided some key guidelines for the application of DfMA in manufacturing, as shown in Table 1. Their focal points are mainly related to design, fabrication, assembly, and materials. From Table 1, it is clear that simplification and the assembly process are spotlighted. The guidelines are descriptive and qualitative, with no quantitative, implementable, and 
numerical details that are easy to comprehend and execute. While some of the principle aspects are relevant to construction, the guidelines when proposed did not necessarily consider the heterogeneity of construction.

Table 1. A non-exhaustive list of DfMA guidelines

\begin{tabular}{|c|c|c|c|c|}
\hline & Guidelines & $\begin{array}{l}\text { Persp } \\
\text { ective } \\
\text { S }\end{array}$ & Benefits & $\begin{array}{l}\text { Refere } \\
\text { nce }\end{array}$ \\
\hline 1 & Aim for mistake-proof design & SD & $\begin{array}{l}\text { Avoids unnecessary re-work, improve quality, } \\
\text { reduce time and costs }\end{array}$ & $\begin{array}{l}\text { 1); } 2 \text {; } \\
\text { (3); } 4\end{array}$ \\
\hline 2 & Design for ease of fabrication & $\mathrm{F} ; \mathrm{SP}$ & $\begin{array}{l}\text { Reduces time and costs by eliminating complex } \\
\text { fixtures and tooling }\end{array}$ & $\begin{array}{l}1 \text {; } ; 2 ; \\
\text { (4) }\end{array}$ \\
\hline 3 & $\begin{array}{l}\text { Design for simple part } \\
\text { orientation and handling }\end{array}$ & F; SP & $\begin{array}{l}\text { Reduces time and costs by avoiding non-value } \\
\text { adding manual effort }\end{array}$ & $\begin{array}{l}\text { (1); } 2 \text {; } \\
\text { (4) }\end{array}$ \\
\hline 4 & $\begin{array}{l}\text { Design with a predetermined } \\
\text { assembly technique in mind }\end{array}$ & $\mathrm{F}$ & Reduces time and costs when assembling & (1); (4) \\
\hline 5 & $\begin{array}{l}\text { Design multifunctional and } \\
\text { multi-use parts }\end{array}$ & $\begin{array}{l}\text { F; SP; } \\
\text { SD }\end{array}$ & $\begin{array}{l}\text { Reduces time with fewer manufacture processes } \\
\text { and simplified jointing }\end{array}$ & (2) \\
\hline 6 & Consider modular designs & $\mathrm{SP} ; \mathrm{M}$ & $\begin{array}{l}\text { Reduces time and costs due to simplified design } \\
\text { and assembly }\end{array}$ & $\begin{array}{l}\text { (1); } 2 \text {; } \\
\text { (3); (4) }\end{array}$ \\
\hline 7 & $\begin{array}{ll}\text { Consider } & \text { design } \text { for } \\
\text { mechanized } & \text { or automated } \\
\text { assembly } & \end{array}$ & $\mathrm{SP} ; \mathrm{A}$ & $\begin{array}{l}\text { Improves assembly efficiency, quality, and } \\
\text { security }\end{array}$ & $\begin{array}{l}\text { (1); } 3 \text {; } \\
\text { (4) }\end{array}$ \\
\hline 8 & $\begin{array}{l}\text { Use standard and off-the- } \\
\text { shelf components }\end{array}$ & $\begin{array}{l}\mathrm{SP} ; \\
\mathrm{M} ; \mathrm{SD}\end{array}$ & Reduces purchasing lead time and costs & $\begin{array}{l}\text { (1); } 2 \text {; } \\
\text { (3); } 4 \text {; }\end{array}$ \\
\hline 9 & $\begin{array}{l}\text { Use as similar materials as } \\
\text { possible }\end{array}$ & $\mathrm{SP} ; \mathrm{M}$ & $\begin{array}{l}\text { Reduces time with fewer manufacture processes } \\
\text { and simplified jointing }\end{array}$ & (1); (4) \\
\hline $\begin{array}{l}1 \\
0\end{array}$ & $\begin{array}{l}\text { Use as environmentally } \\
\text { friendly materials as possible }\end{array}$ & & Reduces harm to the environment and residents & (3) \\
\hline $\begin{array}{l}1 \\
1\end{array}$ & Minimize the part count & SP & $\begin{array}{l}\text { Reduces time and costs with simplified design, } \\
\text { manufacture, and assembly }\end{array}$ & $\begin{array}{l}\text { (1); } 2 \text {; } \\
\text { (3); } 4 \text {; }\end{array}$ \\
\hline $\begin{array}{l}1 \\
2\end{array}$ & $\begin{array}{l}\text { Minimize and standardise } \\
\text { connector types and quantity }\end{array}$ & $\begin{array}{l}\text { SP; } \\
\text { SD }\end{array}$ & $\begin{array}{l}\text { Reduces time and costs with simplified design, } \\
\text { manufacture, assembly, repair and maintenance }\end{array}$ & $\begin{array}{l}\text { (1); } 2 \text {; } \\
\text { (3); } 4\end{array}$ \\
\hline $\begin{array}{l}1 \\
3\end{array}$ & $\begin{array}{l}\text { Minimize the use of fragile } \\
\text { parts }\end{array}$ & SP & $\begin{array}{l}\text { Reduces costs due to fewer part failures, and } \\
\text { easier handling and assembly }\end{array}$ & (1); 4 \\
\hline $\begin{array}{l}1 \\
4\end{array}$ & $\begin{array}{l}\text { Do not over-specify } \\
\text { tolerances or surface finish }\end{array}$ & F; SP & Reduces time and costs with easier manufacture & (1); (4) \\
\hline
\end{tabular}

Note: $\mathrm{A}=$ Automation; $\mathrm{F}=$ Flexibility; $\mathrm{M}=$ Modularity; $\mathrm{SD}=$ Standardization; $\mathrm{SP}=$ Simplification.

(1)=Bogue, 2012; (2)=Stoll, 1986; (3)=Emmatty and Sarmah, 2012; (4)=Swift and Brown, 2013

\section{Similarities and differences between manufacturing and construction}

Transplanting DfMA guidelines from manufacturing to construction first requires understanding the connections and distinctions between the two industries. Manufacturing can be defined as "the process of transforming materials and information into goods for the satisfaction of human needs" (Chryssolouris, 2013). It is often linked to the concept of "mass 
production", evolving to successfully adopt machinery and information technologies to achieve cost-effective production (Lanigan, 1992; Crowley, 1998). Construction can also be considered as production process with products that are location-based and involve heavier onsite assembly, e.g., buildings, bridges, roadways, and other infrastructure (Jewell et al., 2014). It is a projectbased activity employing huge human, material, and machine resources and involving heavy investment (Chitkara, 1998).

Manufacturing and construction share many managerial practices, however. For example, they both engage multiple stakeholders to participate in the design, procurement, production, and logistics and supply chain management (LSCM) process (Winch, 2003). The process of producing physical products can be intensive, and thus requires skilled labor and a high level of technology (Sanvido et al., 1990). In recent years, as construction shifts towards prefabrication and other manufacturing techniques, the distinctions between these two industries have blurred. Some scholars advocate construction as a manufacturing process, intending to encourage adoption of manufacturing processes and guidelines (e.g., Crowley, 1998; Gann, 1996). The underpinning idea is to make the construction process more controllable to alleviate the long-lasting problems of the industry such as low efficiency, poor quality control, and labor shortage.

Still, construction differs from manufacturing in its end products and production process. Construction outputs are generally more sophisticated (Sanvido et al., 1990). Unlike manufacturing goods produced at factories and transported to end users, construction outputs are largely built in place (Paez et al., 2005). The unique features of construction outputs lead to the more dynamic, highly localized, and complex nature of construction process. For example, construction involves an onsite production cycle that could last for years and many contingencies and risks can occur during this period (Koskela, 1992; Paez et al., 2005). It is challenging for proactive planning, visual control, and orderly management (Aapaoja and Haapasalo, 2014). Compared to manufacturing with its relatively standardized workflow, construction is a highly localized activity that involves using locally available resources and taking into account local geographic, economic, social and climatic constraints (Akanni, et al., 2015). The site-specific, one-of-a-kind nature of construction projects makes it difficult to apply a standardized routine that has been proved efficient by other projects (Koskela, 1992; Jewell et al., 2014; Aapaoja and Haapasalo, 2014).

Even though offsite construction is quite similar to manufacturing and hence presents an unprecedented opportunity for DfMA, they are not the same. Some major components can be manufactured, e.g., in an offsite precast yard, but a considerable portion of the construction and assembly work are still conducted onsite. Full modular integrated construction has never been the ultimate choice ( $\mathrm{Lu}$ et al., 2018). Construction LSCM of raw materials and precast components play a key role in the success or failure of prefabrication construction (Zhong et 
al., 2017). The final products are still location-based, confined by site conditions and bespoke requirements from diverse clients. As shown in Table 2, the differences mentioned above are summarized into six perspectives, including place, power, mode, form, period, and process. All these features together necessitate a closer look at "general" manufacturing DfMA guidelines to propose a set of guidelines that are more construction-oriented.

Table 2. Difference between manufacture industry and construction industry

\begin{tabular}{|l|l|l|}
\hline Perspectives & Manufacture industry & Construction industry \\
\hline Place & Lowly localized activity & Highly localized activity \\
\hline Power & Factory mechanization & Labor-intensive onsite \\
\hline Mode & Mass production & Customized design \\
\hline Form & Product-based activity & Project-based activity \\
\hline Period & Short cycle & Long cycle \\
\hline Process & Standardized workflow & Non-standardized workflow \\
\hline
\end{tabular}

\section{Tentative DfMA guidelines for construction}

Several studies have tried to apply DfMA in construction, as shown in Table 3. Most of these guidelines directly adopted the manufacturing-oriented DfMA (see Table 1) or made some adaption, mainly by changing their descriptions . Gbadamosi et al. (2019) generalized the fourcategory of guidelines by considering DfMA and lean construction and developed a DfMAbased optimizer for improving constructability. Kim et al. (2016) employed DfMA to overcome the limitations of current bridge construction practice and to realize the standardization of bridge construction in the UK. Chen and Lu (2018) reported DfMA guidelines for curtain wall system specifically. Banks et al. (2018) introduced DfMA to support high-rise residential construction. Safaa et al. (2019) proposed DfMA-based evaluation criteria for the prefabricated bridge.

However, these studies do not adequately discuss the DfMA guidelines applied. Meanwhile, some of the stated guidelines are inconsistent with current architectural and engineering design practices. Hence, they cannot represent the core ideas of DfMA, such as improving manufacturability and assemblability without reducing flexibility and functionality. Many DfMA guidelines only consider reducing cost and number of components, not maintaining and balancing other building attributes, and therefore cannot be used directly. More seriously, these guidelines may make sense when being implemented individually, but can be easily contradictory to each other if being applied together. Therefore, more systematic and iterated guidelines need to be developed.

Considering context specificity and technical limitations, this study treats DfMA implementation as a multi-criteria decision-making (MCDM) issue in the evaluation and optimization of manufacturability and assemblability. Through systematical consideration, 
these guidelines can be assigned importance weights during project process to achieve overall optimization. Therefore, this research derive the five construction-oriented DfMA guidelines shown in Table 4. The generalization of these guidelines is grounded based on the combined consideration between existing DfMA guidelines and construction characteristics. Most of the guidelines mentioned in Table 3 are summarized into component-integrated design which is more closed to manufacture-oriented DfMA. Part of the guidelines are summarized into material-lightened design, logistics-optimized design, and technology-rationalized design. In addition, the inherent differences between the construction and manufacturing industries lead to a new DfMA guideline - context-based design - for construction because the construction is generally a highly localized activity (Akanni et al., 2015). Detailed descriptions of these five guidelines are shown as follows.

Table 3. Some construction-related DfMA guidelines reported in the literature

\begin{tabular}{|c|c|c|c|}
\hline & $\begin{array}{l}\text { Refer } \\
\text { ence }\end{array}$ & Guidelines & Sources \\
\hline \multirow[t]{4}{*}{1} & \multirow{4}{*}{$\begin{array}{l}\text { Gbad } \\
\text { amosi } \\
\text { et al., } \\
\text { (2019 } \\
\text { ) }\end{array}$} & (1) ease of assembling parts & $\begin{array}{l}\text { Minimize and standardise connector types and } \\
\text { quantity ( } 1 \text {; ; (2); (3); (4)); Use standard and off- } \\
\text { the-shelf components (1); (2); (3); (4)) }\end{array}$ \\
\hline & & (2) ease of handling parts & $\begin{array}{l}\text { Design for simple part orientation and handling } \\
\text { (1); (2); (4)); Minimize the part count (1); (2); } \\
\text { (3); (4)) }\end{array}$ \\
\hline & & $\begin{array}{l}\text { (3) speed of assembling the whole } \\
\text { system }\end{array}$ & $\begin{array}{l}\text { Design with a predetermined assembly } \\
\text { technique in mind ( (1); (4)) }\end{array}$ \\
\hline & & (4) waste produced during operation & $\begin{array}{l}\text { Use as environmentally friendly materials as } \\
\text { possible (3) }\end{array}$ \\
\hline \multirow[t]{4}{*}{2} & \multirow{4}{*}{$\begin{array}{l}\text { Kim } \\
\text { et al., } \\
(2016 \\
)\end{array}$} & (1) simplification in design & $\begin{array}{l}\text { Design for ease of fabrication (1); (2); (4)); } \\
\text { Design for simple part orientation and handling } \\
\text { (1); (2); (4)) }\end{array}$ \\
\hline & & (2) reduced number of parts & Minimize the part count (1); (2); (3); (4)) \\
\hline & & $\begin{array}{l}\text { (3) standardization of commonly } \\
\text { used parts and materials }\end{array}$ & $\begin{array}{l}\text { Minimize and standardise connector types and } \\
\text { quantity (1); (2); (3); (4)); Use as similar } \\
\text { materials as possible (1); (4)) }\end{array}$ \\
\hline & & $\begin{array}{l}\text { (4) ease of orientation, handling and } \\
\text { assembly of parts }\end{array}$ & $\begin{array}{l}\text { Design for simple part orientation and handling } \\
\text { (1); (2); (4)) }\end{array}$ \\
\hline \multirow[t]{2}{*}{3} & \multirow{2}{*}{$\begin{array}{l}\text { Chen } \\
\text { and } \\
\text { Lu } \\
\text { (2018 } \\
\text { ) }\end{array}$} & $\begin{array}{l}\text { (1) reducing the part count of curtain } \\
\text { wall system }\end{array}$ & Minimize the part count (1); (2); (3); (4)) \\
\hline & & $\begin{array}{l}\text { (2) reducing the numbers of unique } \\
\text { fasteners necessary to assemble the } \\
\text { curtain wall system on the } \\
\text { construction site }\end{array}$ & $\begin{array}{l}\text { Minimize and standardise connector types and } \\
\text { quantity (1); (2); (3); (4)) }\end{array}$ \\
\hline
\end{tabular}




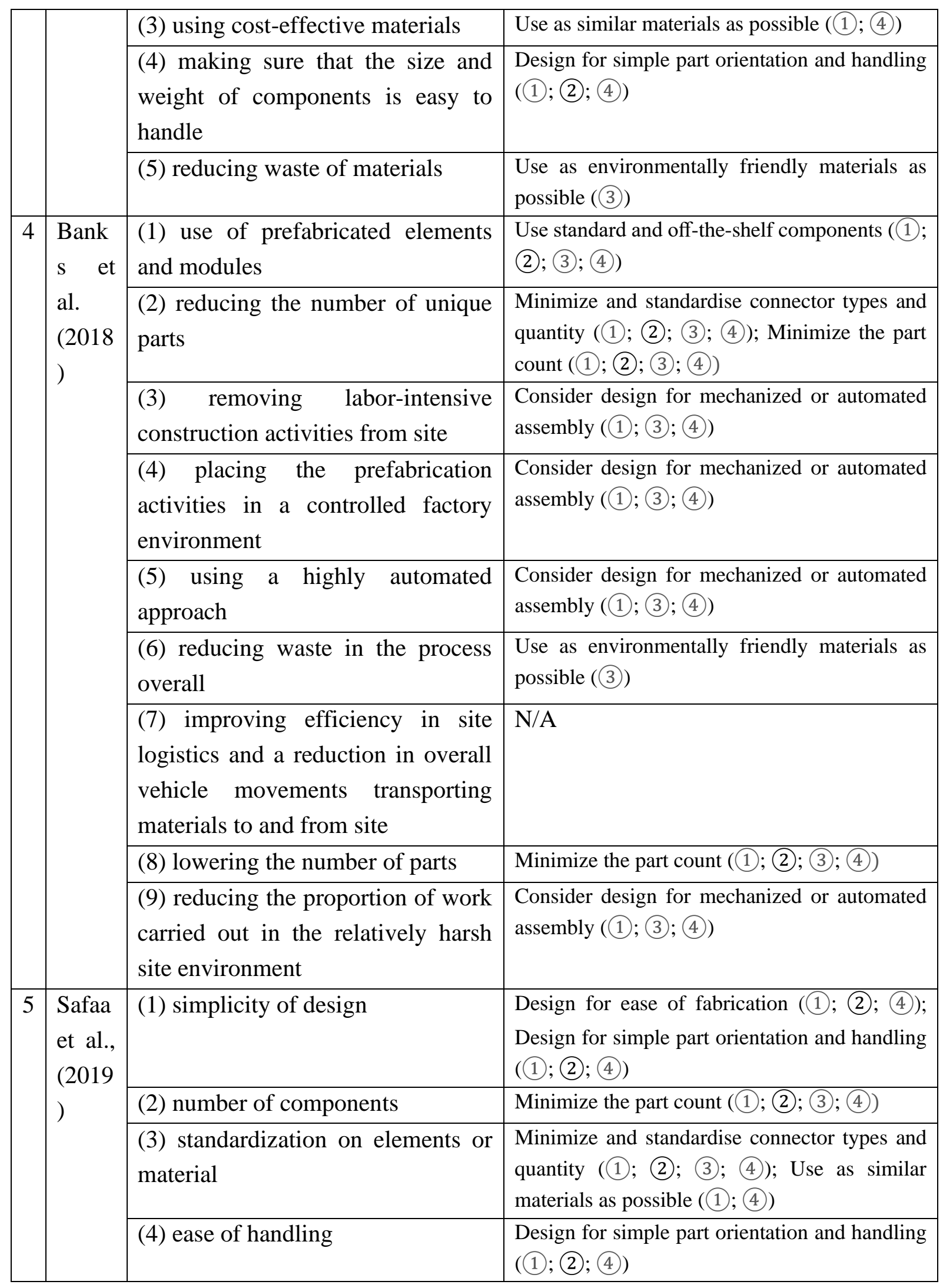

Table 4. Construction-oriented DfMA guidelines proposed in this study

\begin{tabular}{l|l|l} 
Guidelines & Perspectives & Generation sources
\end{tabular}




\begin{tabular}{|c|c|c|c|c|}
\hline NO. & & & $\begin{array}{l}\text { Existing } \\
\text { guideline } \\
\mathrm{S}\end{array}$ & $\begin{array}{l}\text { Construction } \\
\text { characteristi } \\
\text { cs }\end{array}$ \\
\hline \multirow[t]{2}{*}{1} & \multirow[t]{2}{*}{ Context-based design } & Physical site & & $X$ \\
\hline & & Cultural locality & & $\mathrm{X}$ \\
\hline \multirow[t]{2}{*}{2} & \multirow{2}{*}{$\begin{array}{l}\text { Technology-rationalized } \\
\text { design }\end{array}$} & Onsite craftsmanship & & $\mathrm{X}$ \\
\hline & & Off-site prefabrication & $X$ & \\
\hline \multirow[t]{2}{*}{3} & \multirow[t]{2}{*}{ Logistics-optimized design } & Logistics inside the site & & $\mathrm{X}$ \\
\hline & & $\begin{array}{l}\text { Logistics outside the } \\
\text { factory }\end{array}$ & $\mathrm{X}$ & \\
\hline \multirow[t]{2}{*}{4} & \multirow{2}{*}{$\begin{array}{l}\text { Component-integrated } \\
\text { design }\end{array}$} & Finished surface & $\mathrm{X}$ & \\
\hline & & Connection joints & $\mathrm{X}$ & \\
\hline \multirow[t]{2}{*}{5} & \multirow[t]{2}{*}{ Material-lightened design } & Material properties & $\mathrm{X}$ & \\
\hline & & Structural system & & $\mathrm{X}$ \\
\hline
\end{tabular}

\section{Context-based design}

For DfMA implementation in construction, context-based design is conducted from both physical site and cultural locality perspectives. Building process performance is highly influenced by context (McHarg, 1992; Kalay, 1999; Gifford, 2007), and manufacturability and assemblability are two important indicators of this performance. The physical, cultural, social, and other environments in which a building is embedded not only have an impact on the form of the building, but also on the building process. These factors provide references for the building design and process. As shown in Figure 2, different contexts cause different construction results. Seda, a traditional Chinese minority area, relies on mountains to build layers of wooden houses. High-density cities like Hong Kong utilize concrete for high-rise buildings. Old European towns, like Siena, build using bricks and stones. Based on the specific context, building practitioners can use localized craftsmanship, technology, and materials to tackle the difficulties in manufacturing and assembly process without compromising building quality and historical continuity. Thus, the context-based design method adapts the building process to the context to enhance manufacturability and assemblability.

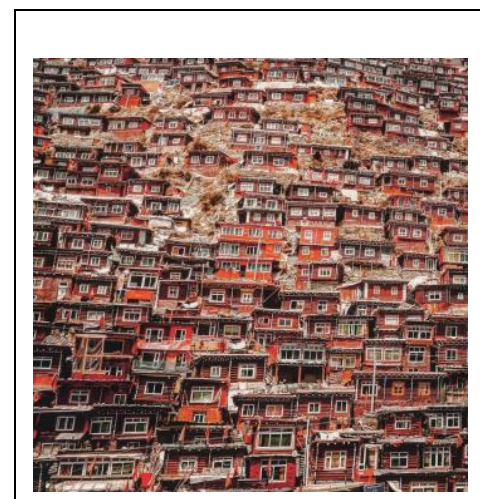

(a) Wood (Seda, Sichuan, China)

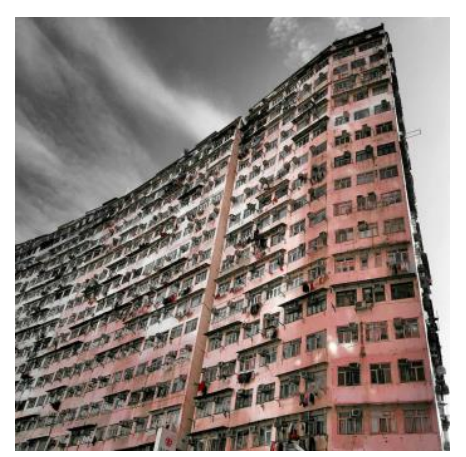

(b) Concrete (Hong Kong, China)

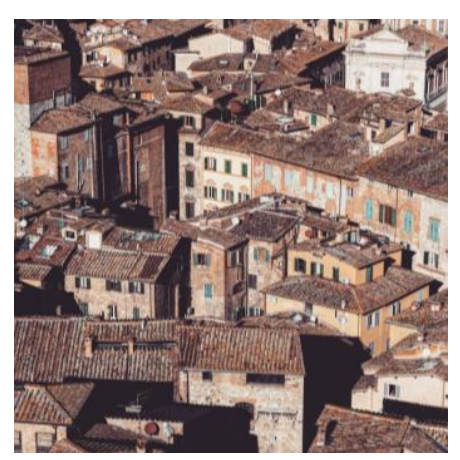

(b) Stone (Siena, Italy) 
Fig. 2. Context-based buildings (source: photo by authors)

\section{Technology-rationalized design}

Increase of manufacturability and assemblability does not have an absolute positive correlation with the depth of adoption of new technologies. Appropriate technology is seen as a more sensible approach than "rocket technology" in the construction industry (Ofori, 1994; Mitropoulos and Tatum, 1999; Lu, 2017). For example, Lu et al. (2018) recommended the implementation of an optimal rather than a high degree of prefabrication. Tan et al. (2019) highlighted the technology implementation barriers in different contexts and advocated appropriate technology implementation strategies. DfMA is considered an ideal way for prefabricated building production in many studies. Since it is not a case of "the higher the degree of prefabrication, the better", the corresponding DfMA strategies must also change with the degree of prefabrication for better manufacturability and assemblability.

\section{Logistics-optimized design}

Optimizing construction logistics has a positive impact on the building process (Sobotka et al., 2005; Vidalakis et al., 2011; Lu et al., 2011). Compared with manufacturing production, building process, which involves off-site factories and onsite assembly, is complicated in terms of LSCM. Therefore, unlike Boothroyd (2005), architectural DfMA should not only consider the building product itself, but also LSCM. Banks et al. (2018) mentioned that DfMA needs to improve efficiency in site logistics and reduction in overall vehicle movements transporting materials to and from the site. It is necessary to consider the effectiveness of component transport and onsite placement on site when carrying out detailed design. Both logistics inside the site and outside the factory need to be considered interconnectedly.

\section{Component-integrated design}

The selection and combination of building components at the design stage is important to a construction project and requires knowledge of engineering, materials, and building equipment. Component-integrated design based on component characteristics and construction logic can improve manufacturability and assemblability. For example, Zhang et al. (2018) proposed a high-speed, integrated component design method for modular houses whereby large components are assembled at the site factory, and aloft work and complex assembly operations are moved to the construction ground. Halfawy and Froese (2007) proposed a component-based framework for project system integration. These measures of integration improve assembly efficiency and reduce dangerous aloft work, which greatly reduces onsite safety hazards while improving the efficiency of onsite construction equipment and tools.

\section{Material-lightened design}

Lightweight buildings first emerged to alleviate the problems of manufacturing overcapacity and lack of social housing after World War II. Therefore, from birth, the lightweight building 
is a product highly related to industrialized production. The material-lightened design represents the material and structural efficiency when creating the volume of space. It is also the impact of the overall construction on the environment as little as possible. Both light timber (Scotta et al., 2015) and light steel (Jackson, 2016) have been appraised for rapidity of realization, affordability, and flexibility in design and construction. Chen and Lu (2018) also highlighted the importance of easy-to-handle size and weight of components in DfMA. Reduction in overall building weight helps to improve efficiency in activities related to manufacturing and assembly. Production, transportation, and onsite manual work become more convenient, as does subsequent demolition and relocation of the building. Under the materiallightened design guideline, architectural design must consider not only the properties of the material but also the weight reduction and achievement of the ideal stiffness-to-weight ratios. It is also necessary to consider the structural system design of the building to achieve overall weight optimization at the system level.

\section{A case study of a construction project pioneering DfMA-oriented design}

The selected case is a housing project located in Yunnan Province, China. It adopted a prefabricated light steel-frame. The project was carried out by a real estate company under the impetus of the Chinese government's policy of taking targeted measures to help people lift themselves out of poverty. The case is analysed in view of the five construction-oriented DfMA guidelines as proposed by this study.

With regards to context-based design principle, the project adapted to the undulating terrain through the underlying steel structural pillars while adopting ethnic minority Dai-style architecture as seen in Figure 3. Figure 4 shows that topological deformation combinations, planned courtyards, and entrance locations were organized into different residential space modes according to different context conditions. Using context-based design principle, design choices were more culturally and geographically adaptable and able to reflect local characteristics.

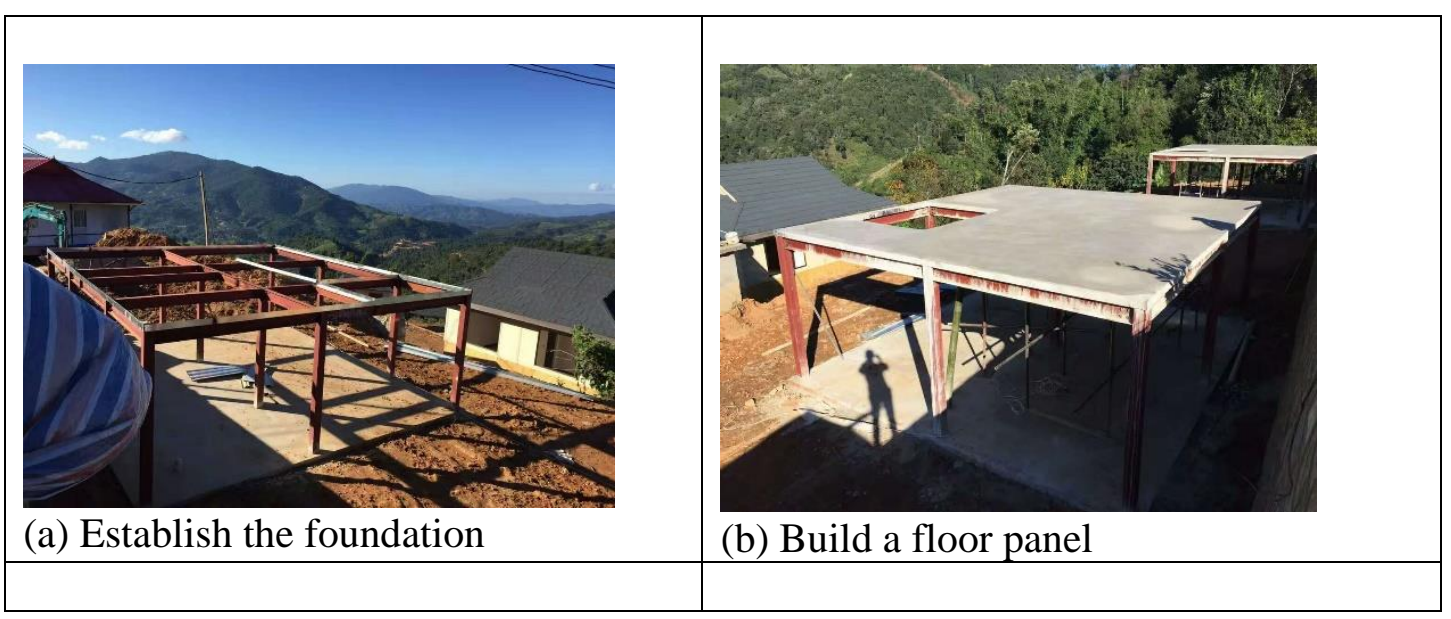




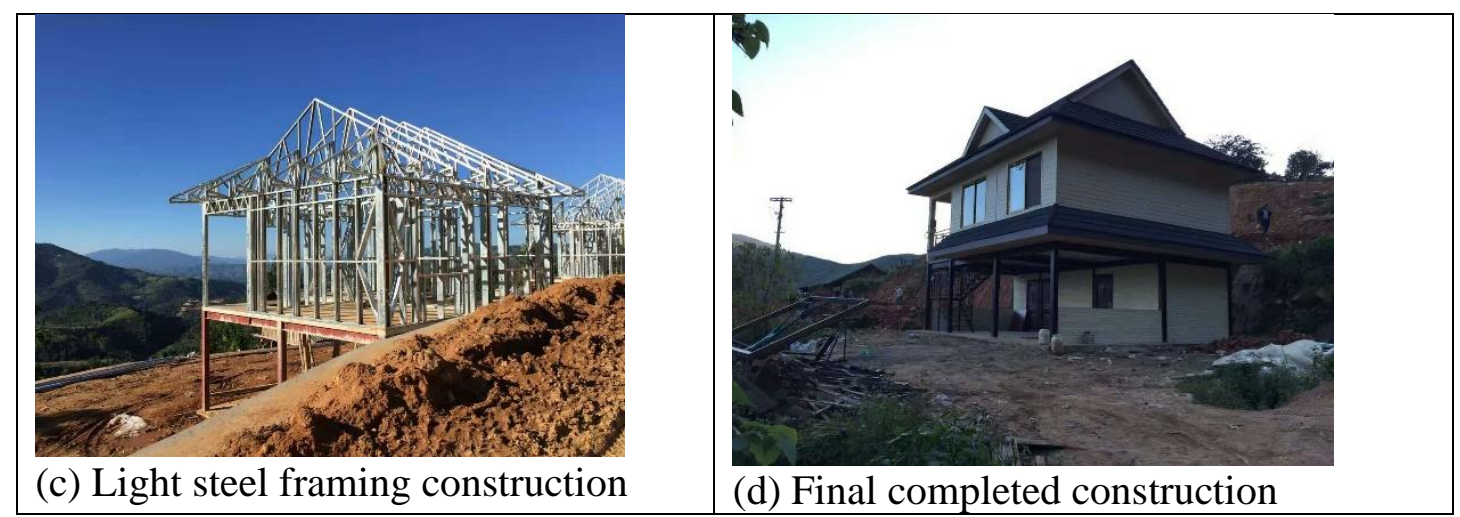

Fig. 3. Building process (source: photo by authors)
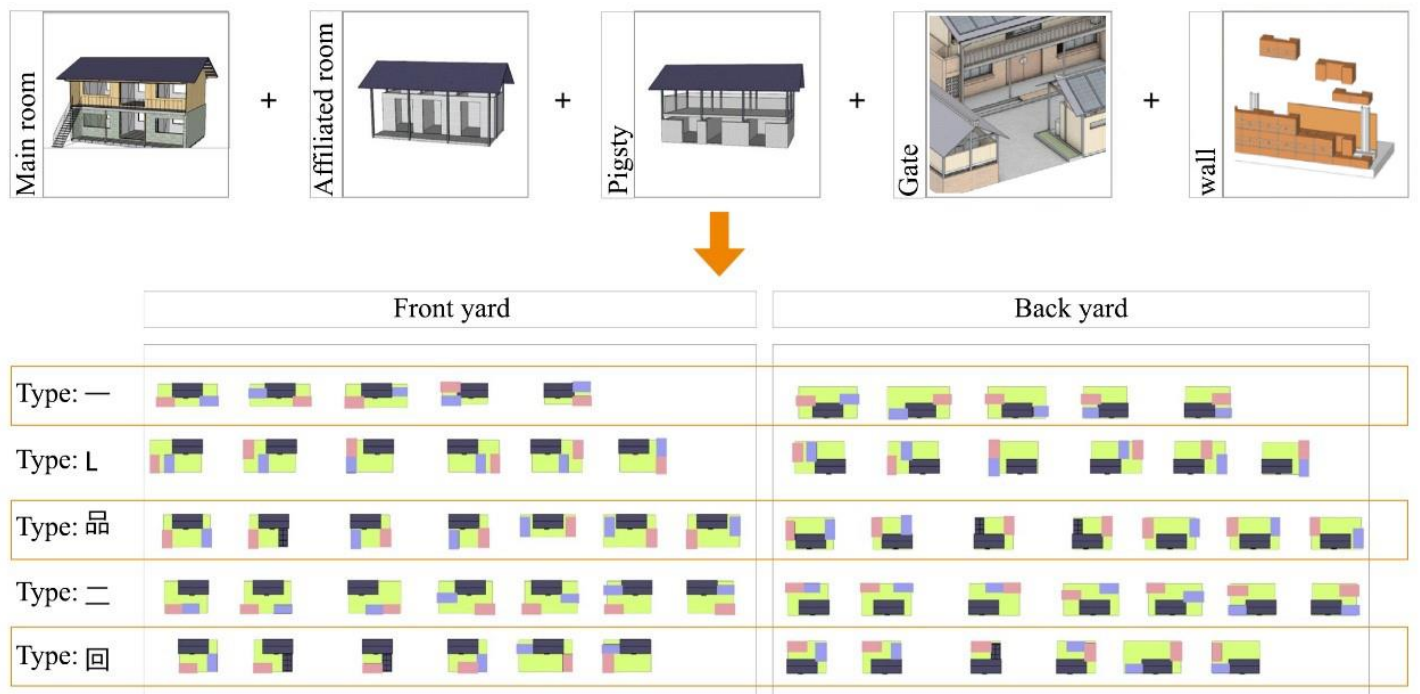

Fig. 4. Design under the site context

As for material-lightened design principle, this project is lightweight, of high strength and small footprint, adopting a light steel-frame structure with high-efficiency lightweight thin-walled profiles. The light steel framing system saves construction time and cost to a large extent. This design highly responded to the integration of material properties and building structure system. The structure is adaptable, the materials easy to recycle, and the project with low waste. Scotta et al., (2015), Jackson (2016) and Chen and Lu (2018) all highlighted the importance of weight in rapidity of realization. The lightweight steel-framed structure is likely to be close to zero energy consumption in terms of energy and environmental performance of the building, reducing waste during manufacturing and assembly (Roque and Santos, 2017; Santos and Silva, 2017). Due to factors such as environmental awareness and wood shortages, countries including the U.S., Japan, the U.K, and Australia are actively promoting the application and development of low- and medium-rise light steel structure houses.

In this project, the component-integrated design principle was consciously considered; the production of components was automated, continuous, and highly precise. Product specifications, especially connection joints and finished surface, were serialized, finalized, and 
matched. It is easy to enlarge the column spacing and provide more separation space, which can reduce the height and increase the building area (the saleable area can reach up to 92\%). Based on the component-integrated design, the advantages of adding floors, building renovation, and building reinforcement are easily perceivable, as shown in Figure 5. Villagers decided the size of the residential area to be built according to the actual situation of their own homes, and they were able to reserve the land for later development. As shown in Figure 6, according to their actual needs, the villagers could freely combine the components of the façade in the available material library to form different effects and styles. These design strategies provided flexibility and expandability for assembly based on component-integrated design.
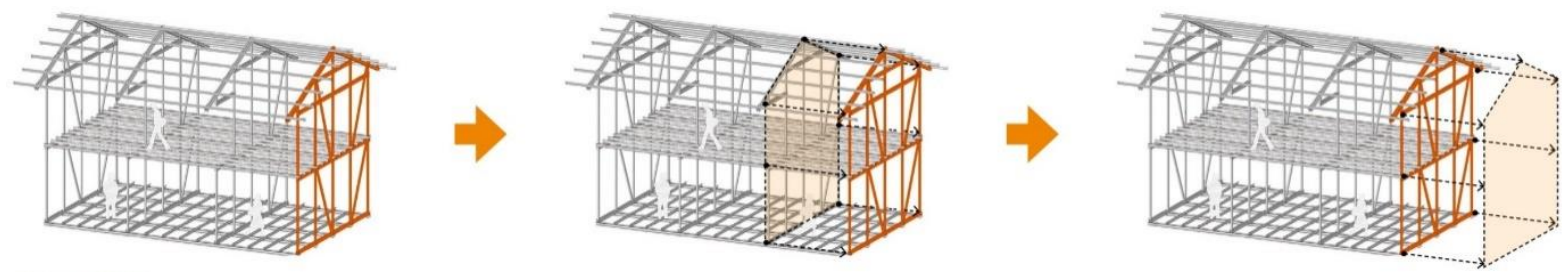

Fig. 5. Assembly expandability

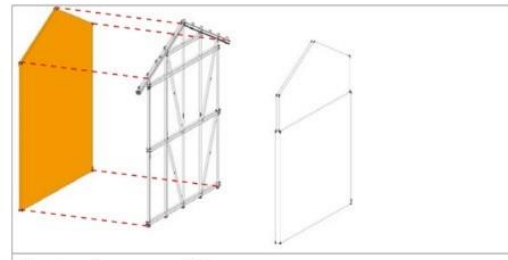

Interior wall:


Fig. 6. Facade material

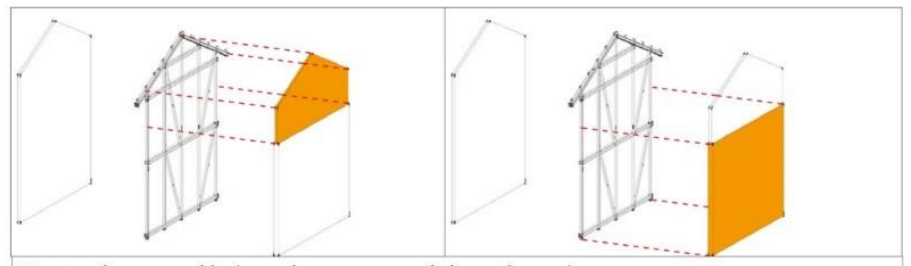

Exterior wall (various combinations):
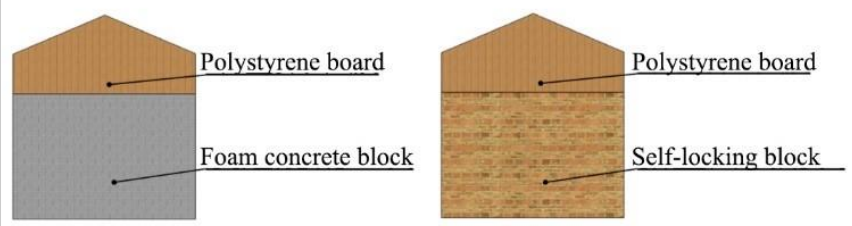

Bamboo-wood plywood

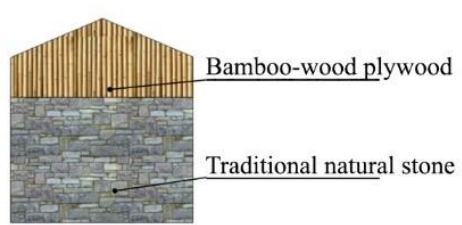

This project also considered the logistics-optimized design principle in view of the difficulties of logistics in the rural areas of Yunnan, where much of the terrain features tall mountains without proper roads. The lightweight material reduced transport pressures and the design of the components also took into account the size requirements of the transport. After the prefabricated modules had been delivered to the site, the construction activities were carried out immediately by the villagers, who learned and helped each other to complete the assembly 
process of the houses. All dry works were carried out with little impact from the weather. A building of about $300 \mathrm{~m}^{2}$ required only five workers and 30 working days to construct.

For the technology-rationalized design principle, this project used low-tech but suitable technology to facilitate rapid construction by ordinary farmer workers and combined onsite craftsmanship and off-site prefabrication. For example, as shown in Figure 7, a new type of mortar-free and self-locking block was used. It can be recycled and used economically and environmentally. Unlike the traditional brick-concrete structure, the masonry can be bonded without relying on cement mortar. This saved labor costs and speeded up the building process. In addition, after the blocks were connected to the wall, the mechanical strength of the wall was increased, which can effectively mitigate the damage caused by earthquakes, typhoons, humidity, and floods.

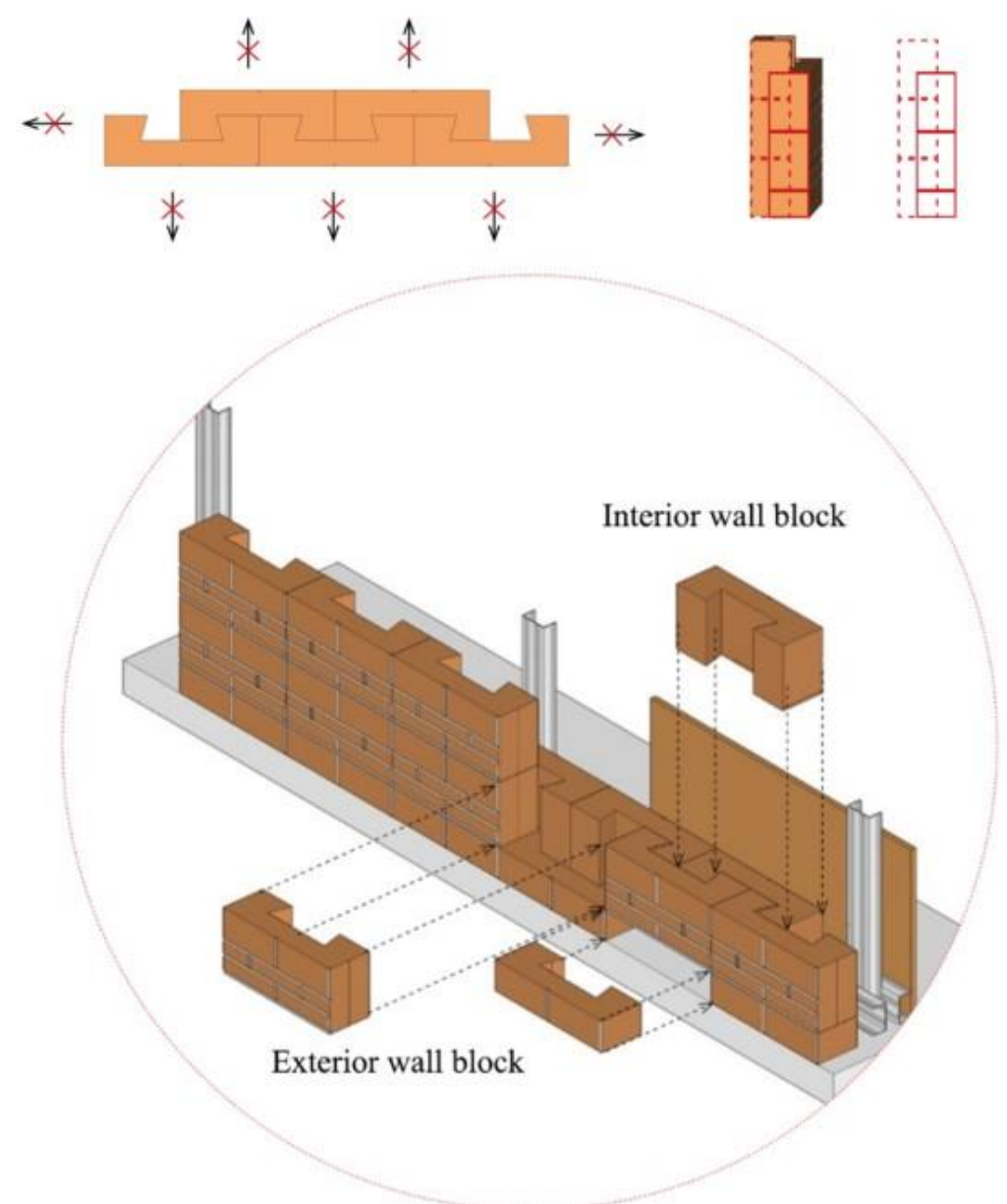

Fig. 7. Brick wall construction method

\section{Discussion}

Traditional DfMA guidelines were developed from a manufacturing perspective. Although they make sense in some situations, architects complain that the guidelines ignore other critical elements such as site conditions, cultural context, flexibility of building forms, and LSCM. Some architects believe that architecture should not be just an industrial product, but rather an 
organic product of the urban environment. Based on these conflicting opinions, the use of context-based design is proposed as a fundamental DfMA guideline. When implementing it, designers should pay attention to both physical and cultural issues related to the site, and try to make use of these characteristics for manufacturing and assembly.

In addition to interdisciplinary integration from manufacturing to construction, the adoption of technology is seen as an important factor affecting manufacturing and assembly. Technology can transform transportation methods, module components, and material processing. Thus, the second guideline is regarded as an enabler for DfMA implementation. The specific context determines the background, obstacles, results, and effects of technology implementation. In addition, various places, especially remote areas, may retain their own unique construction craftsmanship. Some forms of buildings, for example, have high requirements for onsite craftsmanship. Therefore, appropriate degree of prefabrication should be set for achieving optimal manufacturability and assemblability.

Optimization of the logistics is often overlooked at the design stage because architects often consider a building as a static product, rarely treating it as a building process. For architects to consider logistics, they need knowledge of project management and LSCM. This requires the architect to be more than just a designer, but also a coordinator of different types of work and a project manager to guide the building process. When it is impossible for an architect to possess all the knowledge of logistics, it is recommended to get construction or facility managers involved early in the design phase to perform, e.g. a buildability check, or pre-occupancy evaluation.

Component-integrated design and material-lightened design are also set as the constructionoriented guidelines. The prefabrication degree of each project may be different, resulting in different proportions of prefabricated components vs. cast in-situ. These two guidelines emphasize the integrated design of components and the lightweight design of materials. For the former, this study proposes to guide the production of components based on the finished surface of the building and to focus on the design of connection joints. The design from the finished surface to the detail can help the manufactured product to be closer to the final assembly requirements. Standardization of connection joints also increases the efficiency of manufacturing and assembly. For the latter, this study argues that reducing the weight of the material as much as possible will help DfMA implementation, as also evident in Gerth et al. (2013), Chen and Lu (2018), Roque and Santos (2017), and Santos and da Silva (2017). Utilizing the properties of materials means maximizing the use of physical properties and minimizing material modifications. These measures reduce the level of demand for total processing time. The emphasis on structural system design is to break down the limitations of single material consideration. From the whole system, it reduces the consumption required to process materials, thereby increasing manufacturability and assemblability. 
It worth noting that these five guidelines may not have equal weight in every construction project. Due to the uniqueness of each project, it is necessary to change the importance of these guidelines in actual practice. For example, in remote areas, logistics-optimized design would weight higher than other four guidelines. Likewise, prefabrication and cast in-situ will also have different importance weights under different circumstances. Therefore, when implementing the DfMA guidelines proposed in this study, one should evaluate their weights rather than treating them equally each time. By doing so, with due respect to creativity and imagination in design, DfMA inevitably involves an iteration of MCDM that can be assisted by techniques such as Weighted Sum Method, Analytic Hierarchy Process, and Technique for Ordered Preference (Singh and Malik, 2014).

\section{Conclusion}

DfMA is both a design philosophy and methodology with a long history in the manufacturing industry. It has many advocates in the construction industry, who believe that DfMA can alleviate longstanding problems such as lackluster productivity, time delay, cost overrun, and poor safety. While there are considerable differences between manufacturing and construction in terms of production processes and final products, the resurgence of offsite prefabrication construction provides an unprecedented opportunity to adapt DfMA to construction.

Based on a critical investigation of existing DfMA guidelines and the similarities and differences between manufacturing and construction, we propose five construction-oriented DfMA guidelines. First, DfMA must consider context-based design because a construction project must attach to a land within a physical, natural, and cultural context. Second, building technologies provide unlimited options for construction but their availability and efficiency must be considered under a DfMA technology-rationalized guiding principle. Third, DfMA in manufacturing considers parts carefully but rarely their LSCM. In contrast, LSCM play a pivotal role in construction for both cast in-situ and offsite prefabrication construction. Therefore, DfMA in construction must consider the logistics-optimized design principle. Fourth, different levels of onsite and offsite distribution, and different levels of individual and integrated parts are major considerations in conducting a construction project. Therefore, DfMA must consider component-integrated designs. Fifth, materials are related to all the above guiding principles. Use of lightweight materials while guaranteeing structural efficiency is captured by the principle that DfMA must consider material-lightened designs.

The case study conducted in this study illustrated that the guidelines proposed in this study are rooted in the general DfMA guidelines but considers the heterogeneity of construction. It can be further decomposed into more detailed, operable sub-guidelines. Apparently, these construction-oriented DfMA guidelines can operate individually or collectively. The research helps to deepen the application of this new design philosophy in the construction industry 
through proposing five more construction-oriented guidelines. In practice, these guidelines provide direct design guidance to designers, which in turn can lead to significant improvements in manufacturability and assemblability.

The guidelines proposed in this study are not exhaustive. Future studies are recommended to develop other architecture and construction-oriented DfMA guidelines and practices, with a view to improving design and construction. Some areas are particularly critical for such research efforts, e.g., (1) DfMA guidelines for onsite fabrication and prefabrication; (2) DfMA guidelines for different roles, such as project managers and designers; and (3) a standard/method for selecting guidelines, and measuring the degree of implementation and its improvement of manufacturability and assemblability.

\section{Data Availability Statement}

Some or all data, models, or code that support the findings of this study are available from the corresponding author upon reasonable request.

\section{References}

Aapaoja, A., \& Haapasalo, H. (2014). The challenges of standardization of products and processes in construction. In Proceedings of the 22nd Annual Conference of the International Group for Lean (pp. 983-993).

Akanni, P. O., Oke, A. E., \& Akpomiemie, O. A. (2015). Impact of environmental factors on building project performance in Delta State, Nigeria. HBRC Journal, 11(1), 91-97.

Arashpour, M., Miletic, M., Williams, N., \& Fang, Y. (2018). Design for manufacture and assembly in off-site construction: Advanced production of modular façade systems. In ISARC. Proceedings of the International Symposium on Automation and Robotics in Construction (Vol. 35, pp. 1-6). IAARC Publications.

Ashley, S. (1995). Cutting costs and time with DfMA. Mechanical Engineering, 117(3), 74.

Balfour Beatty (2018). Streamlined construction: Seven steps to offsite and modular building.

Ballard, G., \& Howell, G. (1998). What kind of production is construction? In Proc. 6 th Annual Conf. Int'l. Group for Lean Construction (pp. 13-15).

Banks, C., Kotecha, R., Curtis, J., Dee, C., Pitt, N., \& Papworth, R. (2018). Enhancing highrise residential construction through design for manufacture and assembly-a UK case study. Proceedings of the Institution of Civil Engineers-Management, Procurement and Law, 171(4), 164-175.

Bogue, R. (2012). Design for manufacture and assembly: background, capabilities and applications. Assembly Automation, 32(2), 112-118.

Boothroyd, G. (1994). Product design for manufacture and assembly. Computer-Aided Design, 26(7), 505-520.

Boothroyd, G. (2005). Assembly automation and product design. CRC Press. 
Camacho, D. D., Clayton, P., O'Brien, W. J., Seepersad, C., Juenger, M., Ferron, R., \& Salamone, S. (2018). Applications of additive manufacturing in the construction industry-A forward-looking review. Automation in Construction, 89, 110-119.

Chen, K., \& Lu, W. (2018). Design for manufacture and assembly oriented design approach to a curtain wall system: A case study of a commercial building in Wuhan, China. Sustainability, 10(7), 2211.

Chitkara, K. K. (1998). Construction project management. Tata McGraw-Hill Education.

Chryssolouris, G. (2013). Manufacturing systems: theory and practice. Springer Science \& Business Media.

Corbett, J., Dooner, M., \& Meleka, J. (1991). Design for manufacture: strategies, principles and techniques. C. Pym (Ed.). Reading, MA: Addison-Wesley.

Crowley, A. (1998). Construction as a manufacturing process: Lessons from the automotive industry. Computers \& Structures, 67(5), 389-400.

Crowther, P. (1999). Design for disassembly. BDP environment design guide.

Dainty, A., Moore, D., \& Murray, M. (2007). Communication in construction: Theory and practice. Routledge.

Eastman, C. M. (2012). Design for X: concurrent engineering imperatives. Springer Science \& Business Media.

Egan, J. (1998). Rethinking construction. Department of Environment, Transport and the Region.

Emmatty, F. J., \& Sarmah, S. P. (2012). Modular product development through platform-based design and DfMA. Journal of Engineering Design, 23(9), 696-714.

Fox, S., Marsh, L., \& Cockerham, G. (2001). Design for manufacture: a strategy for successful application to buildings. Construction Management and Economics, 19(5), 493-502.

Gann, D. M. (1996). Construction as a manufacturing process? Similarities and differences between industrialized housing and car production in Japan. Construction Management \& Economics, 14(5), 437-450.

Gao, S., Low, S. P., \& Nair, K. (2018). Design for manufacturing and assembly (DfMA): a preliminary study of factors influencing its adoption in Singapore. Architectural Engineering and Design Management, 14(6), 440-456.

Gatenby, D. A., \& Foo, G. (1990). Design for X (DFX): key to competitive, profitable products. AT\&T Technical Journal, 69(3), 2-13.

Gbadamosi, A. Q., Mahamadu, A. M., Oyedele, L. O., Akinade, O. O., Manu, P., Mahdjoubi, L., \& Aigbavboa, C. (2019). Offsite construction: Developing a BIM-Based optimizer for assembly. Journal of Cleaner Production, 215, 1180-1190.

Gerth, R., Boqvist, A., Bjelkemyr, M., \& Lindberg, B. (2013). Design for construction: utilizing production experiences in development. Construction Management and Economics, $31(2), 135-150$.

Gifford, R. (2007). Environmental psychology: Principles and practice (p. 372). Colville, WA: Optimal books. 
Goulding, J. S., Pour Rahimian, F., Arif, M., \& Sharp, M. D. (2015). New offsite production and business models in construction: priorities for the future research agenda. Architectural Engineering and Design Management, 11(3), 163-184.

Halfawy, M. M., \& Froese, T. M. (2007). Component-based framework for implementing integrated architectural/engineering/construction project systems. Journal of Computing in Civil Engineering, 21(6), 441-452.

Hamidi, M., \& Farahmand, K. (2008). Developing a design for manufacturing handbook. In Proceedings of the 2008 IAJC-IJME International Conference, Paper (Vol. 220).

Harik, R. F., \& Sahmrani, N. (2010). DFMA+, a quantitative DFMA methodology. ComputerAided Design and Applications, 7(5), 701-709.

Huang, G. Q. (2012). Introduction. In Eastman, C. M. (Ed.). Design for X: concurrent engineering imperatives. (1-18). Springer Science \& Business Media.

Jackson, N. (2016). The modern steel house. Taylor \& Francis.

Jewell, C., Flanagan, R., \& Lu, W. (2014). The dilemma of scope and scale for construction professional service firms. Construction Management and Economics, 32(5), 473-486.

Jin, R., Gao, S., Cheshmehzangi, A., \& Aboagye-Nimo, E. (2018). A holistic review of off-site construction literature published between 2008 and 2018. Journal of Cleaner Production, 202, 1202-1219.

Kalay, Y. E. (1999). Performance-based design. Automation in construction, 8(4), 395-409.

Kim, M. K., McGovern, S., Belsky, M., Middleton, C., \& Brilakis, I. (2016). A suitability analysis of precast components for standardized bridge construction in the United Kingdom. Procedia Engineering, 164, 188-195.

Koskela, L. (1992). Application of the new production philosophy to construction (Vol. 72). Stanford, CA: Stanford University.

Kuo, T. C., Huang, S. H., \& Zhang, H. C. (2001). Design for manufacture and design for ' $X$ ': concepts, applications, and perspectives. Computers \& Industrial Engineering, 41(3), 241-260.

Laing O'Rourke (2013). The future of DfMA is the future of construction. Engineering Excellence Journal (2013), 77.

Lanigan, M. (1992). Engineers in business: The principles of management and product design. Addison-Wesley Publishing Company.

Latham, S. M. (1994). Constructing the team.

Lu, W. (2017). Design for ' $X$ ', not for a high index: The proposition of an optimal level of prefabrication construction for different socio-economic technical contexts. In RISUD Annual International Symposium 2017.

Lu, W., Chen, K., Xue, F., \& Pan, W. (2018). Searching for an optimal level of prefabrication in construction: An analytical framework. Journal of Cleaner Production, 201, 236-245.

Lu, W., Ye, K., Flanagan, R., \& Jewell, C. (2013). Developing construction professional services in the international market: SWOT analysis of China. Journal of Management in Engineering, 29(3), 302-313. 
Lu, W., Huang, G. Q., \& Li, H. (2011). Scenarios for applying RFID technology in construction project management. Automation in Construction, 20, 101-106.

Maskell, B. H. (2013). Performance measurement for world class manufacturing: A model for American companies. Productivity Press.

McHarg, I. L. (1992). Design with nature (No. 712: 504.75). John Wiley \& Sons.

Mitropoulos, P., \& Tatum, C. B. (1999). Technology adoption decisions in construction organizations. Journal of Construction Engineering and Management, 125(5), 330-338.

Ofori, G. (1994). Construction industry development: role of technology transfer. Construction Management and Economics, 12(5), 379-392.

Paez, O., Salem, S., Solomon, J., \& Genaidy, A. (2005). Moving from lean manufacturing to lean construction: Toward a common sociotechnological framework. Human Factors and Ergonomics in Manufacturing \& Service Industries, 15(2), 233-245.

Pearce, D. (2003). Environment and business: Socially responsible but privately profitable?. Profile Books.

RIBA (2013). RIBA Plan of Work 2013 Designing for Manufacture and Assembly. RIBA London.

Roque, E., \& Santos, P. (2017). The effectiveness of thermal insulation in lightweight steelframed walls with respect to its position. Buildings, 7(1), 13.

Safaa, Y. P., Hatmoko, J. U. D., \& Purwanggono, B. (2019). Evaluation of the use of prefabricated bridge elements with Design for Manufacture and Assembly (DfMA) criteria. In MATEC Web of Conferences (Vol. 270, p. 05006). EDP Sciences.

Santos, P., \& da Silva, L. S. (2017). Energy efficiency of light-weight steel-framed buildings. Energy Efficient Buildings, 35.

Sanvido, V. E., \& Medeiros, D. J. (1990). Applying computer-integrated manufacturing concepts to construction. Journal of Construction Engineering and Management, 116(2), 365-379.

Scotta, R., Trutalli, D., Fiorin, L., Pozza, L., Marchi, L., \& De Stefani, L. (2015). Light steeltimber frame with composite and plaster bracing panels. Materials, 8(11), 7354-7370.

Singh, A., \& Malik, S. K. (2014). Major MCDM Techniques and their application-A Review. IOSR Journal of Engineering, 4(5), 15-25.

Sobotka, A., Czarnigowska, A., \& Stefaniak, K. (2005). Logistics of construction projects. Foundations of Civil and Environmental Engineering, 6, 203-216.

Stoll, H. W. (1986). "Design for manufacture: An owerwiew." Appl Mech Rev, 39(9), 1356.

Swift, K. G, \& Brown, N. J. (2013). Implementation strategies for design for manufacture methodologies, Proceedings of the Institution of Mechanical Engineers. Part B: Journal of Engineering Manufacture, 217(6), 827-833.

Tan, T., Chen, K., Xue, F., \& Lu, W. (2019). Barriers to Building Information Modeling (BIM) implementation in China's prefabricated construction: An interpretive structural modeling (ISM) approach. Journal of Cleaner Production, 219, 949-959. 
The Economist (2017). The construction industry's productivity problem [Electronic Version]. The Economist. https://econ.st/2RzMkLW, retrieved on April 03, 2019.

Vidalakis, C., Tookey, J. E., \& Sommerville, J. (2011). The logistics of construction supply chains: the builders' merchant perspective. Engineering, Construction and Architectural Management, 18(1), 66-81.

Winch, G. (2003). Models of manufacturing and the construction process: the genesis of reengineering construction. Building Research \& Information, 31(2), 107-118.

Wolstenholme, A., Austin, S. A., Bairstow, M., Blumenthal, A., Lorimer, J., McGuckin, S., ... \& Guthrie, W. (2009). Never waste a good crisis: a review of progress since Rethinking Construction and thoughts for our future. London: Constructing Excellence.

Yuan, Z., Sun, C., \& Wang, Y. (2018). Design for Manufacture and Assembly-oriented parametric design of prefabricated buildings. Automation in Construction, 88, 13-22.

Zhang H., Luo S., Tang S., \& Li Y. (2018). Conceptual House for the Future: Architecture Expansion Based on C-house Construction, Performance, Humanities and Design. Architectural Journal, 603(12), 105 -109. (in Chinese).

Zhong, R., Peng, Y., Xue, F., Fang, J., Zou, W., Luo, H., Ng. S.T., Lu, W.S., Shen, Q.P., and Huang, G.Q. (2017). Prefabricated construction enabled by the Internet-of-Things. Automation in Construction, 76(4), 59-70. 